\title{
WEIGHT GAIN FROM SIMPLE OVEREATING. II. SERUM LIPIDS AND BLOOD VOLUME ${ }^{1}$
}

\author{
BY JOSEPH T. ANDERSON, ADRIAN LAWLER, AND ANCEL KEYS \\ (From the Laboratory of Physiological Hygiene, University of Minnesota, Minneapolis, and \\ Mental Health Research Laboratory, Hastings State Hospital, Hastings, Minn.)
}

(Submitted for publication July 26, 1956; accepted October 4, 1956)

Many questions about the processes and events in the reduction of obesity in man are still obscure or even unexplored, in spite of a very large number of clinical and experimental studies. The reverse situation, the production of obesity in man, has had practically no detailed attention except for scattered clinical observations in rare pathological states. That obesity develops whenever a positive calorie balance is maintained over a long period of time, is axiomatic but not very informative.

Positive calorie balance may, of course, reflect increased calorie intake, decreased output, or both, and the details of metabolism and physiological adjustments are not necessarily the same in these several conditions. It would be expected, in fact, that the effects of a sharp reduction in physical activity without change in the diet must be quite different from those of increased diet and no alteration in activity. In the "natural" (spontaneous) development of obesity in organically healthy man which is so common in our modern society, alterations both in calorie intake and output are probably involved and, in addition, the character of the diet is often changed. What factors, then, are responsible for the various morphological, biochemical, and physiological differences between the person before and after the development of obesity?

Animal experiments on these questions are useful, of course, but the relationships in the production of obesity in the rat or other laboratory animals are not quantitatively transferable to the human situation. We have elected to begin the study of these questions in man by the experimental production of obesity by simple overfeeding without substantial change in physical activity, using for this purpose a diet in which the calorie increase is provided one-third by fat and two-thirds by

1 Aided by research grants from the National Dairy Council, Chicago, The Nutrition Foundation, New York, and the Williams-Waterman Fund, New York. carbohydrate. This means, in effect, the kind of dietary change that results when there is no change in the diet except for more liberal use of bread and potatoes, together with such fat as is ordinarily eaten with these. The proportion of fat in the diet is thereby not increased and actually is somewhat reduced. This is important because we know that increasing the proportion of fat in the diet will of itself elevate the blood cholesterol concentration, and one of our main concerns was to separate the effects of fattening and the total calorie intake from the effects of increasing the participation of dietary fat in the total metabolism. Following an initial standardization period of six weeks, overfeeding of 20 men under controlled conditions for 20 weeks resulted in an average body weight gain of $10.6 \mathrm{~kg}$. (23 lbs.), and gains of 19.7 to $22.2 \mathrm{~kg}$. (43 to $49 \mathrm{lbs}$.) in the four men who were most successfully persuaded to eat more than their previous wont. The character of the tissue gained has been reported by Keys, Anderson, and Brozek (1). The present paper reports the findings on the serum lipid concentrations, the blood volume, and the total circulating lipids.

\section{METHODS}

Subjects. The subjects were 20 schizophrenic men patients, aged 33 to 45 , of the Hastings State Hospital who appeared to be free from metabolic peculiarities (1). Some of their relevant characteristics are summarized in Table I. They were of average to moderately tall stature ( 5 feet 5 inches to 6 feet 3 inches, average 5 feet 10 inches) and were not remarkable in their initial condition relative to fatness though they tended to be a little thin. In terms of relative body weight, according to the age and height standards customarily used in the United States, Medico Actuarial, 1912 (2), they averaged 90 per cent (range 73 per cent to 113 per cent).

The diet. During the preliminary standardization period (of six weeks), the food consumption of each man was measured and adjusted in an effort to keep weight constant and to discover the individual balance points. The diet was primarily the regular hospital diet, with some alterations to make for simplicity of manipulation 
and quantitative measurement. The diets which most closely approximated calorie equilibrium in the 20 individuals averaged 2800 calories and contained $125 \mathrm{gm}$. of protein, $305 \mathrm{gm}$. of carbohydrate and $120 \mathrm{gm}$. of total fats, 39 per cent of the calories coming from the latter source. The diet was fully adequate in vitamins and minerals.

For the period of experimental overfeeding this basic diet was supplemented by larger offerings with encouragement to eat more at the regular meals, and by providing between-meal snacks. The supplementary food consumption averaged $108 \mathrm{gm}$. of carbohydrate and $22 \mathrm{gm}$. of fat. The mean protein consumption was the same as in the pre-fattening period although individual subjects made changes in both directions. Food was given in measured portions and all rejections were weighed. Samples of the pooled basic diet and of the supplements were analyzed.

Methods. Blood studies were made on two occasions in the last 3 weeks of the preliminary standardization period and at five-week intervals during overfeeding. The final tests were made at 21 and 23 weeks. All bloods were drawn at rest in the post-prandial state. Hematocrit measurement and serum separation were carried out at once and the other analyses started within a few hours, the serum remaining under refrigeration meanwhile. All analyses were done in duplicate.

Serum cholesterol was measured with the Liebermann-
Burchard reaction applied to the Bloor extract (3). Four fresh cholesterol standards were included in each batch of samples and readings were made on the Evelyn photoelectric colorimeter (660 millimicron filter) at the time of maximum color development at $25^{\circ} \mathrm{C}$. This method has more recently been replaced by a slightly modified form (4) of the method of Abell, Levy, Brodie, and Kendall (5) which involves saponification prior to the eventual estimation with the Liebermann-Burchard reagent. The latter values can be predicted from the former by multiplication by the factor 0.836 (6).

Plasma volume was determined by dilution of Evans Blue dye (T-1824) using essentially the method of Gibson and Evelyn (7). The solution injected contained approximately $15 \mathrm{mg}$. of Evans Blue, $500 \mathrm{mg}$. NaSCN and 1 gram antipyrine in $20 \mathrm{ml}$. isotonic saline. Plasma volume was computed from heparinized plasma samples taken at 20,30, and $40 \mathrm{~min}$. Hematocrit determinations were done by centrifuging the heparinized blood in Wintrobe tubes for 1 hour at 800 times gravity.

The $S_{f}$ 12-20 lipoproteins of serum are those components which when suspended in a medium of 1.063 specific gravity and subjected to the intense gravitational field of the ultracentrifuge undergo flotation at rates between 12 and 20 Svedberg units. The determination of these fractions was done in the Spinco model $E$ ultracentrifuge using techniques described by Gofman and his associates $(8-10)$, as modified by the Committee on

TABLE I

Pre-fattening characteristics of the subjects and body weights during overeating

\begin{tabular}{|c|c|c|c|c|c|c|c|}
\hline \multirow[b]{2}{*}{ Subject } & \multirow{2}{*}{$\begin{array}{l}\text { Age* } \\
\text { (years) } \\
\text { Start }\end{array}$} & \multirow{2}{*}{$\begin{array}{c}\text { Relative } \\
\text { body weight } \\
(\%) \\
\text { Start }\end{array}$} & \multicolumn{5}{|c|}{$\begin{array}{c}\text { Body weight } \\
(\text { kg. })\end{array}$} \\
\hline & & & Start & 5 wks. & 10 wks. & 15 wks. & 20 wks. \\
\hline $\begin{array}{l}\text { Er } \\
\text { Lo } \\
\text { Pro } \\
\text { He } \\
\text { Sa } \\
\text { Be } \\
\text { Br } \\
\text { Fo } \\
\text { Pu } \\
\text { Do } \\
\text { An } \\
\text { Hu } \\
\text { Su } \\
\text { Hi } \\
\text { To } \\
\text { Pra } \\
\text { We } \\
\text { Ma } \\
\text { Dr } \\
\text { Mu }\end{array}$ & $\begin{array}{l}34 \\
38 \\
45 \\
35 \\
39 \\
35 \\
41 \\
39 \\
34 \\
42 \\
41 \\
40 \\
33 \\
45 \\
44 \\
41 \\
33 \\
43 \\
44 \\
33\end{array}$ & $\begin{array}{r}101 \\
99 \\
113 \\
89 \\
86 \\
91 \\
86 \\
101 \\
90 \\
90 \\
75 \\
73 \\
109 \\
85 \\
98 \\
74 \\
86 \\
80 \\
77 \\
99\end{array}$ & $\begin{array}{l}71.9 \\
68.2 \\
90.2 \\
67.8 \\
75.7 \\
67.0 \\
66.6 \\
69.3 \\
76.2 \\
60.5 \\
56.6 \\
51.5 \\
73.6 \\
68.4 \\
88.5 \\
56.1 \\
63.9 \\
65.6 \\
56.3 \\
73.3\end{array}$ & $\begin{array}{l}75.8 \\
71.4 \\
93.4 \\
72.3 \\
80.8 \\
73.3 \\
70.8 \\
74.0 \\
79.0 \\
62.8 \\
57.8 \\
52.5 \\
74.5 \\
68.2 \\
91.7 \\
\mathbf{5 7 . 5} \\
\mathbf{6 7 . 1} \\
\mathbf{6 7 . 6} \\
\mathbf{5 9} .5\end{array}$ & $\begin{array}{l}84.4 \\
78.5 \\
98.5 \\
77.4 \\
85.5 \\
78.1 \\
74.1 \\
77.6 \\
83.9 \\
64.9 \\
60.4 \\
54.5 \\
74.9 \\
71.1 \\
94.7 \\
61.9 \\
67.3 \\
69.5 \\
\mathbf{5 9 . 9} \\
75.2\end{array}$ & $\begin{array}{r}87.7 \\
82.2 \\
104.5 \\
81.2 \\
88.2 \\
79.6 \\
76.3 \\
79.5 \\
86.4 \\
66.6 \\
61.6 \\
55.1 \\
76.7 \\
71.9 \\
95.3 \\
63.4 \\
67.9 \\
69.4 \\
60.0 \\
76.4\end{array}$ & $\begin{array}{r}94.2 \\
89.2 \\
111.1 \\
87.5 \\
93.5 \\
82.2 \\
80.8 \\
82.4 \\
86.8 \\
69.9 \\
64.4 \\
57.2 \\
79.2 \\
73.8 \\
93.2 \\
60.7 \\
67.8 \\
69.5 \\
59.0 \\
75.8\end{array}$ \\
\hline $\begin{array}{l}\text { No. } \\
\text { Mean } \\
\text { S.D. }\end{array}$ & $\begin{array}{l}20 \\
39.0 \\
\pm 4.3\end{array}$ & $\begin{array}{r}20 \\
90.1 \\
+11.3\end{array}$ & $\begin{array}{r}20 \\
68.4 \\
\pm 9.9\end{array}$ & $\begin{array}{r}19 \\
71.0 \\
+10.7\end{array}$ & $\begin{array}{r}20 \\
74.6 \\
+11.4\end{array}$ & $\begin{array}{r}20 \\
76.5 \\
+12.4\end{array}$ & $\begin{array}{r}20 \\
78.9 \\
+13.9\end{array}$ \\
\hline
\end{tabular}

* Nearest birthday.

$\dagger$ Standard Deviation $=\sqrt{\frac{N_{2 X^{2}-(2 X)^{2}}}{N(N-1)}}$.

$\ddagger$ As percentage of the average for equal height and age in the standard Medico-Actuarial tables. 
TABLE II

Serum lipids and blood characteristics

\begin{tabular}{|c|c|c|c|c|c|c|c|c|c|c|c|c|c|}
\hline \multirow[b]{2}{*}{ Subject } & \multicolumn{5}{|c|}{$\begin{array}{l}\text { Serum cholesterol } \\
\text { (mg. per } 100 \mathrm{ml} . \text { ) }\end{array}$} & \multicolumn{2}{|c|}{$\begin{array}{c}S_{\ell} 12-20 \\
\text { (mg. per } 100 \mathrm{ml} \text { ) }\end{array}$} & \multicolumn{3}{|c|}{$\begin{array}{l}\text { Plasma volume } \\
\text { (liters) }\end{array}$} & \multicolumn{3}{|c|}{$\begin{array}{c}\text { Hematocrit } \\
(\%)\end{array}$} \\
\hline & Start & $\begin{array}{c}5 \\
\text { wks. }\end{array}$ & $\begin{array}{c}10 \\
\text { wks. }\end{array}$ & $\begin{array}{c}15 \\
\text { wks. }\end{array}$ & $\begin{array}{c}20 \\
\text { wks.* }\end{array}$ & $\begin{array}{c}10 \\
\text { wks. }\end{array}$ & $\begin{array}{c}20 \\
\text { wks. }\end{array}$ & Start* & $\begin{array}{c}10 \\
\text { wks. }\end{array}$ & $\underset{\text { wks.* }}{20}$ & Start & $\begin{array}{c}10 \\
\text { wks. }\end{array}$ & $\begin{array}{c}20 \\
\text { wks. }\end{array}$ \\
\hline $\begin{array}{l}\mathrm{Er} \\
\mathrm{Lo} \\
\mathrm{Pro} \\
\mathrm{He} \\
\mathrm{Sa} \\
\mathrm{Be} \\
\mathrm{Br} \\
\mathrm{Fo} \\
\mathrm{Pu} \\
\mathrm{Do} \\
\mathrm{An} \\
\mathrm{Hu} \\
\mathrm{Su} \\
\mathrm{Hi} \\
\mathrm{To} \\
\mathrm{Pra} \\
\mathrm{We} \\
\mathrm{Ma} \\
\mathrm{Dr} \\
\mathrm{Mu}\end{array}$ & $\begin{array}{l}205 \\
273 \\
273 \\
281 \\
248 \\
191 \\
220 \\
239 \\
192 \\
221 \\
197 \\
181 \\
202 \\
272 \\
223 \\
227 \\
193 \\
284 \\
221 \\
227\end{array}$ & $\begin{array}{l}252 \\
293 \\
297 \\
322 \\
259 \\
220 \\
205 \\
283 \\
220 \\
254 \\
207 \\
190 \\
218 \\
292 \\
238 \\
274 \\
186 \\
294 \\
224\end{array}$ & $\begin{array}{l}249 \\
384 \\
288 \\
310 \\
256 \\
234 \\
242 \\
284 \\
233 \\
226 \\
202 \\
208 \\
204 \\
312 \\
219 \\
250 \\
204 \\
332 \\
228 \\
186\end{array}$ & $\begin{array}{l}225 \\
370 \\
330 \\
317 \\
258 \\
226 \\
206 \\
270 \\
215 \\
259 \\
203 \\
209 \\
228 \\
306 \\
223 \\
246 \\
190 \\
296 \\
222 \\
226\end{array}$ & $\begin{array}{l}225 \\
376 \\
373 \\
310 \\
244 \\
188 \\
237 \\
274 \\
206 \\
226 \\
216 \\
226 \\
230 \\
322 \\
218 \\
248 \\
193 \\
311 \\
220 \\
200\end{array}$ & $\begin{array}{r}32 \\
46 \\
\\
21 \\
24 \\
22 \\
13 \\
15 \\
3 \\
\\
29 \\
14 \\
18 \\
13\end{array}$ & $\begin{array}{l}66 \\
90 \\
\\
38 \\
72 \\
38 \\
27 \\
23 \\
37 \\
\\
17 \\
57 \\
59 \\
24 \\
33 \\
18 \\
58 \\
41 \\
18 \\
16\end{array}$ & $\begin{array}{l}2.72 \\
2.88 \\
3.95 \\
2.71 \\
3.17 \\
2.72 \\
2.83 \\
2.83 \\
3.55 \\
2.78 \\
2.62 \\
2.54 \\
2.84 \\
3.08 \\
3.62 \\
2.59 \\
3.04 \\
2.46 \\
2.84 \\
2.97\end{array}$ & $\begin{array}{l}3.20 \\
3.29 \\
3.60 \\
2.51 \\
2.90 \\
3.34 \\
2.77 \\
3.08 \\
3.52 \\
2.97 \\
2.77 \\
2.80 \\
3.00 \\
2.83 \\
3.66 \\
2.99 \\
3.16 \\
2.96 \\
2.76 \\
3.24\end{array}$ & $\begin{array}{l}2.58 \\
2.93 \\
4.00 \\
2.55 \\
3.53 \\
3.38 \\
2.82 \\
3.07 \\
3.75 \\
2.49 \\
2.86 \\
2.56 \\
3.11 \\
3.33 \\
3.93 \\
2.54 \\
2.88 \\
2.92 \\
2.76 \\
3.33\end{array}$ & $\begin{array}{l}40.6 \\
44.7 \\
43.8 \\
47.0 \\
43.7 \\
47.7 \\
46.7 \\
46.4 \\
41.8 \\
43.8 \\
45.4 \\
45.6 \\
44.8 \\
41.1 \\
45.9 \\
45.8 \\
42.6 \\
51.0 \\
44.9 \\
45.7\end{array}$ & $\begin{array}{l}40.2 \\
48.2 \\
44.0 \\
50.6 \\
49.7 \\
49.8 \\
50.4 \\
45.4 \\
46.3 \\
46.0 \\
48.4 \\
46.6 \\
45.2 \\
44.0 \\
45.5 \\
48.1 \\
46.2 \\
53.1 \\
46.4 \\
45.4\end{array}$ & $\begin{array}{l}41.4 \\
46.5 \\
42.4 \\
49.1 \\
45.2 \\
48.6 \\
47.9 \\
46.4 \\
46.6 \\
46.5 \\
47.0 \\
45.2 \\
45.0 \\
42.3 \\
46.9 \\
46.2 \\
44.8 \\
52.4 \\
45.4 \\
45.0\end{array}$ \\
\hline $\begin{array}{l}\text { No. } \\
\text { Mean } \\
\text { S.D. } \dagger\end{array}$ & $\begin{array}{r}20 \\
228.5 \\
33.2\end{array}$ & $\begin{array}{r}19 \\
248.8 \\
40.8\end{array}$ & $\begin{array}{r}20 \\
252.6 \\
51.1\end{array}$ & $\begin{array}{r}20 \\
251.2 \\
48.9\end{array}$ & $\begin{array}{c}20 \\
252.2 \\
56.7\end{array}$ & $\begin{array}{l}13 \\
21.6 \\
11.03\end{array}$ & $\begin{array}{l}18 \\
40.7 \\
21.72\end{array}$ & $\begin{array}{c}20 \\
2.936 \\
0.382\end{array}$ & $\begin{array}{c}20 \\
3.068 \\
0.307\end{array}$ & $\begin{array}{c}20 \\
3.067 \\
0.469\end{array}$ & $\begin{array}{r}20 \\
44.95 \\
2.40\end{array}$ & $\begin{array}{r}20 \\
46.98 \\
2.89\end{array}$ & $\begin{array}{c}20 \\
46.04 \\
2.48\end{array}$ \\
\hline
\end{tabular}

* Mean of two determinations.

† Standard deviation.

Lipoproteins and Atherosclerosis, National Advisory Heart Council.

In this laboratory the area measured on the ultracentrifugal pattern for determining the $S_{\&} 12-20$ concentration is bounded by lines drawn at exactly the positions where peaks for $S_{t} 12$ and $S_{t} 20$ particles would fall. In some laboratories the area is measured between $S_{t} 11$ and $S_{f} 21$ lines. Such a method would give higher concentrations of $S_{f}$ 12-20 fraction than we have reported. Duplicate determinations of $S_{\ell}$ 12-20 lipoprotein fraction in each of 10 serum samples gave a coefficient of reliability of 0.75 with a standard error of measurement of $6.8 \mathrm{mg}$. per $100 \mathrm{ml}$. Twenty men were tested twice within two weeks for $S_{t}$ 12-20 lipoprotein and a coefficient of reliability of 0.62 was found with a standard error of measurement of $7.7 \mathrm{mg}$. per $100 \mathrm{ml}$.

\section{RESULTS}

The attempt to persuade the subjects to overeat met with great success in some cases and with little response in others. The elicited increases in calorie intake ranged from 39 per cent to 8 per cent. The mean calorie intakes ( \pm standard deviation) in the last 4 weeks of the preliminary period and in the overfeeding period were $2800( \pm 340)$ and $3430( \pm 490)$ calories, respectively. The effects of 20 weeks of this dietary regimen on serum cholesterol, $S_{\mathbf{f}}$ 12-20 lipoprotein, plasma volume and hematocrit are presented in Table II.

The changes in body weight caused by overnutrition are given in Table I. The greatest gain in body weight was $22.2 \mathrm{~kg}$. in 20 weeks and 8 men gained more than $13 \mathrm{~kg}$. each. In Table III the mean responses of these 8 men to the overnutrition regimen are compared with the mean responses of the group of 9 men who gained least. For most of the men the calorie intake was practically constant from week to week in the overnutrition period and the rate of weight gain was quite uniform throughout the 20 weeks.

The men who gained most weight increased on the average about $40 \mathrm{mg}$. per $100 \mathrm{ml}$. in serum cholesterol concentration during the first 10 weeks of overnutrition ( $25 \mathrm{mg}$. in the first 5 weeks). During the last 10 weeks these men continued to overeat and to gain weight at nearly the same rate but no further change in cholesterol concentration occurred. The men who gained least weight had only a small average increase in serum cholesterol concentration which is not statistically significant. The calculated quantities of total circulating se- 
TABLE III

The responses of two groups of men to attempted overfeeding for 20 weeks *

\begin{tabular}{|c|c|c|}
\hline & $\begin{array}{c}\text { High gain } \\
\text { group } \\
\text { (8 men) }\end{array}$ & $\begin{array}{c}\text { Low gain } \\
\text { group } \\
\text { (9 men) }\end{array}$ \\
\hline \multicolumn{3}{|l|}{ Body weight (kg.) } \\
\hline $\begin{array}{l}\text { At start } \\
\text { Gain in first half } \\
\text { Gain in last half }\end{array}$ & $\begin{array}{l}72.1 \\
9.9 \pm 0.6 \\
8.1 \pm 1.0\end{array}$ & $\begin{array}{l}66.3 \\
3.5 \pm 0.4 \\
0.8 \pm 0.5\end{array}$ \\
\hline \multicolumn{3}{|c|}{$\begin{array}{l}\text { Serum cholesterol concen- } \\
\text { tration }(\mathrm{mg} . / 100 \mathrm{ml} \text {.) }\end{array}$} \\
\hline $\begin{array}{l}\text { At start } \\
\text { Gain in first half } \\
\text { Gain in last half }\end{array}$ & $\begin{array}{r}241 \\
40 \pm 11 \\
-3 \pm 13\end{array}$ & $\begin{array}{r}226 \\
13 \pm 9 \\
3 \pm 5\end{array}$ \\
\hline \multicolumn{3}{|c|}{$\begin{array}{l}\text { Total circulating serum } \\
\text { cholesterol (grams) }\end{array}$} \\
\hline $\begin{array}{l}\text { At start } \\
\text { Gain in first half } \\
\text { Gain in last half }\end{array}$ & $\begin{array}{l}7.23 \\
1.45 \pm 0.64 \\
0.04 \pm 0.75\end{array}$ & $\begin{array}{l}6.50 \\
0.71 \pm 0.35 \\
0.12 \pm 0.34\end{array}$ \\
\hline \multicolumn{3}{|l|}{ Plasma volume ( $\mathrm{ml}$. ) } \\
\hline $\begin{array}{l}\text { At start } \\
\text { Gain in first half } \\
\text { Gain in last half }\end{array}$ & $\begin{array}{r}2976 \\
111 \pm 133 \\
22 \pm 139\end{array}$ & $\begin{array}{r}2885 \\
159 \pm 79 \\
-3 \pm 98\end{array}$ \\
\hline \multicolumn{3}{|l|}{ Blood volume ( $m l)}$. \\
\hline $\begin{array}{l}\text { At start } \\
\text { Gain in first half } \\
\text { Gain in last half }\end{array}$ & $\begin{array}{l}5405 \\
454 \pm 241 \\
-90 \pm 199\end{array}$ & $\begin{array}{r}5267 \\
456 \pm 161 \\
41 \pm 201\end{array}$ \\
\hline
\end{tabular}

* The "high gain group" includes the 8 men who gained between 13 and $22 \mathrm{~kg}$., the "low gain group" includes the 9 men who gained between 2 and $6 \mathrm{~kg}$. Mean values and standard errors $( \pm)$. rum cholesterol (mean \pm standard deviation) for all 20 men were $6.72 \pm 1.42,7.74 \pm 1.74$, and $7.76 \pm 2.34 \mathrm{gm}$. at the start, 10 weeks, and 20 weeks, respectively.

The concentration of the $S_{\mathbf{f}}$ 12-20 lipoproteins in the serum increased from the tenth to the twentieth week of overeating in all but one of the 12 men for whom these measurements are available on both occasions. The mean change was a rise of $22.0 \mathrm{mg}$. per $100 \mathrm{ml}$., and this is significant with a probability for chance occurrence of 0.002 , the $t$ value being 3.97. During this period the serum total cholesterol values for these same 12 men fell by an average of $5.4 \mathrm{mg}$. per $100 \mathrm{ml}$., which is statistically insignificant. There was no correlation between the changes in $S_{f} 12-20$ and those in cholesterol in this interval, the coefficient of correlation being $\mathrm{r}=0.047$. We have no explanation for this finding.

The gain in body weight was accompanied by some tendency to increase in the plasma and whole blood volume. The individual values of plasma volume and hematocrit are listed in Table II. The mean plasma volume increased by 0.13 liters in the first 10 weeks $(P=0.05)$ and remained constant thereafter. The mean hematocrit increased in the first 10 weeks and subsequently decreased by a smaller amount so that it ended above the starting

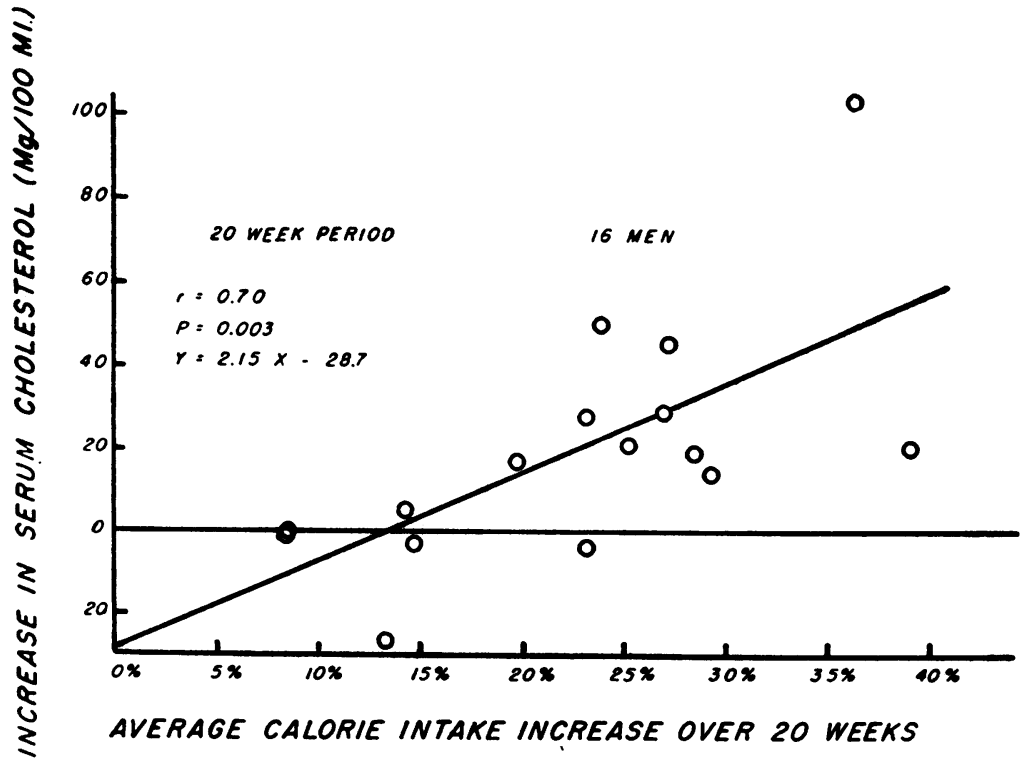

Fig. 1. Relation of the Increase in Serum Cholesterol Concentration to the Average Increase in Caloric Intake 
TABLE IV

Regression of serum cholesterol elevation above the initial level on rate of body weight gain (equation passing through the origin) in men while overeating

\begin{tabular}{|c|c|c|c|c|}
\hline & $\begin{array}{c}5 \\
\text { Weeks }\end{array}$ & $\begin{array}{c}10 \\
\text { Weeks }\end{array}$ & $\begin{array}{c}15 \\
\text { Weeks }\end{array}$ & $\begin{array}{l}20 \\
\text { Weeks }\end{array}$ \\
\hline 1. Number of subjects & 19 & 19 & 20 & 20 \\
\hline $\begin{array}{l}\text { 2. Weight gain rate in } 5 \text { preceding weeks } \\
\text { Mean (gm./day) } \\
\text { Standard deviation (gm./day) }\end{array}$ & $\begin{array}{r}85 \\
\pm 47\end{array}$ & $\begin{array}{r}101 \\
\pm 63\end{array}$ & $\begin{array}{r}54 \\
\pm 40\end{array}$ & $\begin{array}{r}69 \\
\pm 85\end{array}$ \\
\hline $\begin{array}{l}\text { 3. Serum cholesterol elevation above } \\
\text { initial level } \\
\text { Mean } \\
\text { Standard deviation }\end{array}$ & $\begin{array}{r}8.8 \% \\
\pm 8.0 \%\end{array}$ & $\begin{array}{r}11.7 \% \\
\pm 10.4 \%\end{array}$ & $\begin{array}{r}9.6 \% \\
\pm 9.7 \%\end{array}$ & $\begin{array}{r}9.8 \% \\
\pm 12.6 \%\end{array}$ \\
\hline $\begin{array}{l}\text { 4. Regression coefficient of item } 3 \text { on item } 2 \text {, } \\
\text { equation passing through the origin } \\
\text { Standard error }\end{array}$ & $\begin{array}{r}0.085 \\
\pm 0.021\end{array}$ & $\begin{array}{r}0.111 \\
\pm 0.017\end{array}$ & $\begin{array}{r}0.157 \\
\pm 0.028\end{array}$ & $\begin{array}{r}0.104 \\
\pm 0.024\end{array}$ \\
\hline
\end{tabular}

value. All of these differences were statistically significant. Blood volume computed from plasma volume and hematocrit increased significantly in the first half of the experiment and thereafter decreased by a small amount which was not statistically significant. The mean values of blood volume ( \pm standard deviations) for the 20 men were $5.32 \pm 0.63,5.79 \pm 0.54$, and $5.68 \pm 0.87$ at the start, middle and end, respectively. Plasma volume, blood volume and hematocrit mean values were all significantly higher at all times during the weight gaining process than at the start.

The increase in plasma and blood volumes occurred equally in the high-gain and low-gain groups (Table III). These changes in the subgroups do not reach statistical significance chiefly because the number of men in each group is small. The net conclusion of the experiment with respect to plasma and erythrocytes is an indication that overeating caused an increase in both but no evidence that the largest blood increases were associated with the largest body weight gains.

Since all the men were urged to eat as much as possible and each man chose his own rate of eating we do not have two well-defined groups of "gainers" and "non-gainers" but rather a continuous series extending from the man who gained least, $2.5 \mathrm{~kg}$., to the man who gained most, $22.2 \mathrm{~kg}$. Data of this type are not well suited to analysis by grouping and are better treated by correlation methods.

The relationship between increase in serum cholesterol concentration in 20 weeks and increase in rate of eating is presented in Figure 1. There is a marked tendency for the men who increased their calorie intake most to experience the greatest rise in serum cholesterol. The slope of the regression line indicates that a 1 per cent increase in calorie intake continued for 20 weeks resulted in an average increase of $2 \mathrm{mg}$. per $100 \mathrm{ml}$. in serum cholesterol concentration (standard error $0.6 \mathrm{mg}$.). The correlation coefficient between these variables is 0.70 and the probability that this correlation could have arisen due to chance alone is 0.003 .

In many practical situations information is available concerning body weight changes but nothing is known about food consumption. The question may be raised whether an observed gain in body weight can be used to predict an increase in serum cholesterol. Table IV shows the relationship between body weight gain, expressed as rate of gain during the preceding 5 weeks, and serum cholesterol concentration expressed as percentage increase above the initial value. The restriction is imposed that the regression lines should pass through the origin because constant body weight must theoretically correspond to constant serum cholesterol concentration under the conditions of this experiment. On each occasion of cholesterol determination during overfeeding there was a significant positive regression between the hypercholesterolemia and the rate of body weight gain. Each regression coefficient is the percentage elevation of serum cholesterol above the steady-state level corresponding to 1 gram body weight gain per day. The value was significantly greater than zero at each observation during the overeating period. It is inferred that a rise in serum choles- 
terol appeared promptly with overeating, the increase being roughly proportional to the rate of weight gain. But as overeating and gaining weight continued, the serum cholesterol concentration did not tend to change further.

Since determinations of serum $S_{\mathbf{f}}$ 12-20 lipoproteins were made only at the middle and end of the overnutrition period, the change in $\mathrm{S}_{\boldsymbol{t}} 12-20$ lipoproteins in the last ten weeks was tested for correlation with increase in calorie intake and with gain in body weight. No significant correlation was found in either case. During this latter half of the overnutrition period serum cholesterol increase between periods was likewise unrelated to the degree of overeating or weight gain.

The correlation analysis described attempted to answer the question-what change do overeating and the maintenance of a positive calorie balance produce in serum cholesterol and $S_{f} 12-20$ lipoprotein concentrations? It is also pertinent to ask -is there a tendency for men who are overweight to have unusually high concentrations of serum cholesterol or $\mathrm{S}_{\mathrm{t}}$ 12-20 lipoproteins?

Among middle-aged men examined by the Laboratory of Physiological Hygiene, 162 maintained constant relative body weight within 5 per cent for 4 years. In this group of men who varied widely in relative obesity but all of whom were close to calorie equilibrium, there was no correlation between serum cholesterol concentration and relative body weight (correlation coefficient $=$ 0.02 , total number of tests $=648$ ). The overweight men had no higher serum cholesterol concentration than the underweight men. In the men who were overeating and in positive calorie balance, the relationship was different. Using 79 tests on 20 men during the period of overfeeding, the coefficient of correlation was 0.35 between serum cholesterol concentration and relative body weight. This value is small but it is statistically significant $(P=0.004)$. Among these men the most overweight individuals tended to have the highest serum cholesterol concentrations.

Serum $S_{\boldsymbol{f}}$ 12-20 lipoprotein was similar to serum cholesterol in relation to relative weight. In the men who were overeating, 31 tests on 19 men gave a coefficient of correlation of 0.40 between $\mathrm{S}_{\mathrm{f}}$ 12-20 lipoprotein and relative body weight. Although the coefficient is higher, the probability judgment is less decisive in this case $(P=0.025)$ because the number of tests was smaller. Like serum cholesterol, the $S_{f}$ 12-20 fraction showed no correlation with relative weight in the men who were stable in body weight, 73 tests on 72 men resulted in a correlation coefficient of 0.08 .

After the overfeeding experiment was finished the men were allowed to eat as they pleased without any guidance. Eighteen months later 19 of the 20 men were again observed. Seven men had lost more than $10 \mathrm{~kg}$. since the end of overfeeding and 6 of these were among the 9 men who had gained over $10 \mathrm{~kg}$. in the experiment. They showed an average fall of $20 \mathrm{mg}$. of cholesterol and $40 \mathrm{mg}$. of $\mathrm{S}_{\mathrm{f}}$ 12-20 lipoprotein per $100 \mathrm{ml}$. of serum (ranges -57 to -8 and -82 to -10 , respectively) from their values at the end of the overfeeding period. Eleven of the former subjects showed smaller weight changes since the overfeeding period, and this group included 7 of the 9 men who had gained least in the experiment. Their serum cholesterol and $S_{f} 12-20$ concentrations showed a statistically insignificant tendency to rise slightly (averages of +15 and $+10 \mathrm{mg}$. per cent, respectively) from their values at the end of the experiment.

\section{DISCUSSION}

What caused the observed significant increases in serum cholesterol? It has been repeatedly observed that, in calorie equilibrium, a major change in the proportion of calories provided as mixed food fats tends to produce corresponding changes in the concentration of cholesterol and of $S_{\mathrm{f}} 12-20$ lipoprotein in the serum $(9,11-13)$.

In the present experiment the proportion of calories provided by fats was slightly decreased during the overfeeding ( 37 per cent versus 39 per cent), so the present observations might seem discordant with these other findings. However, it will be observed that the absolute amount of fat consumed was increased by an average of 22 gm. per day and such a change in fat consumption under conditions of calorie equilibrium may be expected to produce a rise in serum cholesterol concentration $(14,15)$.

Consideration of these facts might suggest that the serum cholesterol level tends to reflect the total fat ingestion, probably because cholesterol is a necessary part of the lipoprotein fat-transport system in the blood. In calorie equilibrium this load of fat metabolism is directly related to the 
proportion of the total calories consumed as fats but in positive calorie balance the absolute fat intake may be a better measure of the fat metabolism load. But this explanation, without further elaboration, fails to account for the fact that men who are physically active tend, in comparison with less active men in the same population, to have an elevated absolute fat intake but not elevated blood cholesterol values (16). Moreover, when young men greatly increase their energy expenditure by exercise and maintain calorie equilibrium by increasing the diet, the serum cholesterol does not rise in spite of a considerable increase in fat consumption (17).

However, allowance must be made for the fact that when the total rate of energy metabolism is increased, there is normally a parallel increase in the circulatory rate so that the rate of fat transport will be increased even though there is no rise in concentration of the fat, or lipoprotein, in the blood. Accordingly, it would seem that all of the present data are in harmony with the concept that, other things being equal, the serum cholesterol concentration is determined by the fat transport load per unit of circulation imposed on the blood. At calorie equilibrium this is determined by the proportion of the calories presented as fats and this relationship is not altered by increasing the energy level of intake if calorie equilibrium is maintained by increased exercise which normally also involves a proportionate increase in circulatory rate. In positive calorie balance, the fat transport load is obviously increased, even if the character of the diet is constant. Indeed, if fat storage is taking place, that portion of the fat synthesized from carbohydrate in the liver also adds to the transport load so we might expect some serum cholesterol rise even on a reduced fat diet during the active phase of gaining weight. But, if the calorie excess and the weight gain steadily continue, there is no further increase in the fat transport load and the serum cholesterol should remain constant at its newly raised level. Finally, if calorie equilibrium is now achieved and obesity is steady, the serum cholesterol should be expected to approximate that characteristically associated with the proportion of fat in the diet at calorie equilibrium regardless of whether this equilibrium means steady obesity, steady "normality," or steady leanness.
The fat-transport of relevance would seem to be that from intestine to liver and from liver to fat depots. These avenues are active in overnutrition and in high fat ingestion and are inactive in undernutrition and on a low-fat or fat-free regiment. The transport of fat from the depots to the liver and of fat metabolites from the liver to the muscles for burning is less obviously related to serum cholesterol. In undernutrition the serum cholesterol level usually falls though much fat is being transported away from the adipose depots.

The increase of $S_{t} 12-20$ lipoprotein which occurred in the last half of the overfeeding period involved the transfer of only about one-fortieth of the cholesterol of the plasma from one lipoprotein class to another. There is no apparent reason for the difference but this lipoprotein class seems to have exhibited a slower or longer continued response to the increase in food intake than the preponderant cholesterol-bearing fractions.

\section{SUMMARY}

Twenty physically healthy schizophrenic men increased their calorie intakes without changing their physical activity. The diet was substantially constant and fully adequate in proteins and vitamins at all times, the extra calories being provided by adding carbohydrates and a small amount (about one-third of the extra calories) of mixed fats to the standard diet. Thus the total fat intake increased though the proportion of calories from fats fell slightly. Average calorie increases for 20 weeks ranged from 8 per cent to 39 per cent and these produced weight gains from 2.5 to 22.2 $\mathrm{kg}$., the average gain being about $0.5 \mathrm{~kg}$. per week.

The average total serum cholesterol concentration rose $20 \mathrm{mg}$. per $100 \mathrm{ml}$. during the first 5 weeks of overeating and then remained substantially constant at the same elevated level during the next 15 weeks though weight gain continued at the same rate as during the first five weeks. The rise in serum cholesterol concentration in the various individuals tended to be proportional to the rate of weight gain.

The concentration of the $S_{f} 12-20$ lipoprotein fraction in the serum, measured in the ultracentrifuge, tended to increase from the tenth to the twentieth week of overeating though the total serum cholesterol remained constant. 
Weight gain tended to be associated with increase in the circulating plasma and blood volume during the first weeks of overeating with no further change thereafter.

A hypothesis as to the role of cholesterol in fat transport is presented which seems to explain: 1) The increase in serum cholesterol on a high fat diet and in overnutrition with a positive calorie balance; 2) The stability of the serum cholesterol during calorie equilibrium or in a steady state of continuing overnutrition; 3 ) The failure of serum cholesterol to rise when diet calories and energy expenditure are both increased in parallel; and 4) The decrease in serum cholesterol on a low fat diet and in negative calorie balance.

\section{ACKNOWLEDGMENTS}

Acknowledgment is made to the medical staff of the Hastings State Hospital and to Dr. Ralph Rossen, formerly superintendent, for assistance in selection and care of the patients, to Mrs. Helen Williams who served as dietitian and to William Everhart, George Kreps, Donald Border, Robert Stinnette, Jr., Donald Brumbaugh, John Hutcheson, Clyde Nafzinger and Howard Worthen, volunteers of the Brethren Volunteer Service program who assisted in cooking, serving food and managing the patients.

\section{REFERENCES}

1. Keys, A., Anderson, J. T., and Brozek, J., Weight gain from simple overeating. I. Character of the tissue gained. Metabolism, 1955, 4, 427.

2. Association of Life Insurance Medical Directors. Medico-actuarial mortality investigation, 1912, 1.

3. Keys, A., Mickelsen, O., Miller, E. v. O., Hayes, E. R., and Todd, R. L., The concentration of cholesterol in the blood serum of normal man and its relation to age. J. Clin. Invest., 1950, 29, 1347.

4. Anderson, J. T., and Keys, A., Cholesterol in serum and lipoprotein fractions. Its measurement and stability. Clin. Chem., 1956, 2, 145.

5. Abell, L. L., Levy, B. B., Brodie, B. B., and Kendall, F. E., A simplified method for the estimation of total cholesterol in serum and demonstration of its specificity. J. Biol. Chem., 1952, 195, 357.

6. Keys, A., Anderson, J. T., Fidanza, F., Keys, M. H., and Swahn, B., Effects of diet on blood lipids in man, particularly cholesterol and lipoproteins. Clin. Chem., 1955, 1, 34.

7. Gibson, J. G., 2nd, and Evelyn, K. A., Clinical studies of the blood volume. IV. Adaptation of the method to the photoelectric microcolorimeter. J. Clin. Invest., 1938, 17, 153.

8. Gofman, J. W., Lindgren, F., Elliott, H., Mantz, W., Hewitt, J., Strisower, B., Herring, V., and Lyon, T. P., The role of lipids and lipoproteins in atherosclerosis. Science, 1950, 111, 166, 186.

9. Jones, H. B., Gofman, J. W., Lindgren, F. T., Lyon, T. P., Graham, D. M., Strisower, B., and Nichols, A. V., Lipoproteins in atherosclerosis. Am. J. Med., 1951, 11, 358.

10. Gofman, J. W., Jones, H. B., Lindgren, F. T., Lyon, T. P., Elliott, H. A., and Strisower, B., Blood lipids and human atherosclerosis. Circulation, 1950, 2, 161.

11. Keys, A., The relation in man between cholesterol levels in the diet and in the blood. Science, 1950, 112, 79.

12. Keys, A., and Anderson, J. T., The relationship of the diet to the development of atherosclerosis in man, pp. 181-197 in National Academy of Sciences -National Research Council, Symposium on Atherosclerosis, Washington, D. C., 1955 (National Research Council Pub. 338).

13. Gofman, J. W., and Jones, H. B., Obesity, fat metabolism and cardiovascular disease. Circulation, 1952, 5, 514.

14. Anderson, J. T., and Keys, A., Dietary fat and serum cholesterol. Federation Proc., 1953, 12, 169.

15. Anderson, J. T., and Keys, A., Food fats and serum cholesterol. Federation Proc., 1954, 13, 449.

16. Keys, A., Anderson, J. T., Aresu, M., Biörck, G., Brock, J. F., Bronte-Stewart, B., Fidanza, F., Keys, M. H., Malmros, H., Poppi, A., Posteli, T., Swahn, B., and del Vecchio, A., Physical activity and the diet in populations differing in serum cholesterol. J. Clin. Invest., 1956, 35, 1173.

17. Mann, G. V., Tell, K., Hayes, O., McNally, A., and Bruno, D., Exercise in the disposition of dietary calories. Regulation of serum lipoprotein and cholesterol levels in human subjects. New England J. Med., 1955, 253, 349. 